\title{
THE ROLE OF REFUGEE-ESTABLISHED CHURCHES IN INTEGRATING FORCED MIGRANTS: A CASE STUDY OF WORD OF LIFE Assembly in YeOville, JohanNesburg
}

Author:

Vedaste Nzayabino ${ }^{1,2}$

\section{Affiliation:}

${ }^{1}$ Faculty of Humanities, School of Social Sciences, University of the Witwatersrand, South Africa

${ }^{2}$ Department of New Testament Studies, University of Pretoria South Africa

\section{Correspondence to: Vedaste Nzayabino}

email:

vedaste.nzayabino@gmail. com

\section{Postal address:}

PO Box 885, Grafton,

NSW 2460, Australia

Keywords:

religion; migration;

self-integration; identity; belonging

Dates:

Received: 12 June 2009

Accepted: 01 Oct. 2009

Published: 17 June 2010

How to cite this article: Nzayabino, V., 2010,

'The role of refugeeestablished churches in integrating forced migrants: A case study of Word of Life Assembly in Yeoville, Johannesburg', HTS Teologiese Studies/ Theological Studies 66(1), Art. \#290, 9 pages. DOI: 10.4102/hts.v66i1.290

This article is available at: http:/ /www.hts.org.za

\section{Note:}

Vedaste Nzayabino participates as a Research Associate in the research project 'Biblical Theology and Hermeneutics', directed by Prof. Dr Andries G. van Aarde Honorary Professor of the Faculty of Theology at the University of Pretoria, South Africa

\section{ABSTRACT}

The increasing embeddedness of religious issues within contemporary global phenomena has increased the role religion plays in migrants' spiritual, social, and economic lives. Drawing on the findings of the study, conducted within one of the Pentecostal migrant churches in Johannesburg, this paper explored ways in which a (migrant) church shapes a refugee's motivation to integrate and his resultant quest for a transient alternative belonging and inclusion within diasporic communities through church affiliation. Through interviews with members of the Word of Life Assembly (WOLA), one of the independent churches established by forced migrants in Yeoville, the study revealed that refugees tend to integrate themselves within their own churches, while the refugee church itself - labelled a 'foreign' entity by South African community members - works to garner approval and acceptance from South Africans and faith-based institutions. Cultural and linguistic problems were identified as major barriers to a refugee's attempts to integrate into local churches, thereby becoming important issues that need to be considered in the establishment of migrant churches within the South African host community.

\section{INTRODUCTION}

In the process of negotiating their livelihoods in host communities, forced migrants - especially those staying in urban areas - have recourse to a wide range of survival strategies, including small business, employment, studies, and use of local assistance channels and remittances from abroad. Alongside these common coping schemes, another form of coping strategy is increasingly taking shape within refugee communities, especially in Africa: religion. The emergence and, particularly, the influence of this new coping mechanism within refugee communities, has attracted a number of researchers and academics to consider religion and spirituality in studies and debates around forced migration. Thus, Diana Eck (cited in Gozdziak 2002:136), emphatically affirms that today, religion is increasingly a subject of study and that people are becoming increasingly aware of the power of religion in their own societies. Interestingly, this trend is clearly noticeable in the case of forced migration, where refugees tend to become more religious in the host countries than they were in their home countries. In the United States for instance, Warner (2000:2) reports that (South) Korea is approximately 25\% Christian, but $50 \%$ of South Korean immigrants in the US are Christians, and half of the remainder join Christian churches as they proceed to settle down over time. The result is that approximately $75 \%$ of Korean immigrants in the US are Christian.

A similar phenomenon was observed among Burundi refugee youths in Tanzania, among whom, Sommers (2001) points out, there was an exponential increase in church membership, especially within Pentecostal refugees churches. Drawing on the report by the Pentecostal Church Association of Tanzania (PCAT), Sommers indicates that the number of Pentecostal refugees tripled between the mid-1970s and 1992. Another significant fact about this report is that every Burundi refugee youth interviewed, and nearly the entire Burundi refugee community in Dar es Salaam attended Pentecostalist churches' (2001:362).

The fact that migrants become more receptive to religion in host communities than in their home countries suggests that religion plays an important role in their lives as migrants. Both Warner (2000:1) and Portes and Rumbaut (2006:325) note a symbiotic relationship between migration and religion and both come to the conclusion that migration is a 'theologizing experience' because of the challenges and psychological traumas that it poses and because, as Menjivar (2003:25) adds, religion provides an ethical slant and the resources that nourish immigrants' outlook as they react to the confusion and alienation that result from their uprooting. Burwell, Hill and Wicklin (1986:356) explain this theo-migratory dynamic utilising the theories of 'attribution' and 'deprivation' of religion.

According to the attribution theory, Burwell (1986) argues,

refugees who have developed religious attributions are more likely to cope with a trauma associated with the resettlement experience successfully, because religion provides the opportunity to make sense out of a disorderly world.

(Burwell 1986:356)

In particular, Burwell points out that refugees manifesting higher levels of religiosity will be more likely to be better integrated than those with a low level of religiosity.

Conversely, the deprivation theory claims that the less predictable and explainable life has been, the greater the need for an explanatory construct such as religion (Burwell, Hill \& Wicklin 1986:357). In other words, according to the deprivation theory, people who experience deprivations, including social, economic and organismic or traumatic hardships, are more likely to resort to religion as a coping strategy.

( 2010. The Authors. Licensee: OpenJournals Publishing. This work is licensed under the Creative Commons Attribution License. 
The theories of attribution and deprivation have inspired several writers to attempt to expand the role of religion beyond spiritual boundaries. For instance, Fenggang (2001:275) and Kim (1987:233) argue that immigrant congregations are no longer just sites for religious worship; they are also assuming multiple functions, including both religious and secular classes such as the provision of social services, recreational centres, and social spaces for civic functions. Fenggang (2001) gives an illustration of this operational shift by asserting that

like U.S. Christian churches, Buddhist and Hindu temples, Islamic mosques, and Zoroastrian centres are changing from prayer and ritual centres to community centres where immigrants celebrate weddings, conduct funerals, counsel families, provide social services to the needy, hold cultural activities, and so on.

(Fenggang 2001:275)

In other words, most congregants attend churches not only for religious salvation, but also for secular, economic and social reasons (Kim 1987:234). Similarly, the International Organisation for Migration (2006:35) points out that different faiths and practices are to a large extent becoming part of social fabric and are no longer an alien concept to be held at bay, but have become incorporated into the living body politic and human relations.

This article draws on data collected during research for a master's degree in Forced Migration Studies at the University of the Witwatersrand, Johannesburg. The research was conducted between November and December 2004. The study investigated the WOLA, a Pentecostal church established by a Congolese pastor in Yeoville, one of the well-known urban areas in Johannesburg where many migrants reside. This paper strives to explain the complex manner in which a religious institution of a particular nature (Pentecostal Christian) serves and articulates the needs of a vulnerable and stressed community in a cosmopolitan urban setting such as Johannesburg.

\section{DEFINITION OF KEY TERMS}

Before discussing the methods used in the study described above there is a need to clarify some key concepts: refugee, asylumseeker, forced migrant, economic migrant and ethnic identity.

\section{Refugee/forced migrant}

In terms of the 1951 United Nations Convention relating to the Status of Refugees, a refugee is:

A person who owing to a well-founded fear of being persecuted for reasons of religion, nationality, membership of a particular social group or political opinion, is outside the country of this nationality and is unable, or owing to such fear, is unwilling to avail himself of the protection of that country; or who, not having a nationality and being outside the country of his former habitual residence as a result of such events, is unable or, owing to such fear, is unwilling to return to it ....

(UN Convention of 1951, Article 1A [2])

The 1969 Refugee Convention of the Organization of African Unity (OAU), now the African Union (AU), has extended the definition to include a person who,

owing to external aggression, occupation, foreign domination or events seriously disturbing or disrupting public order in either a part or the whole of his or her country of origin or nationality, is compelled to leave his or her place of habitual residence in order to seek refuge elsewhere.

(1969 OAU Refugee Convention, Article 1 [2]; Refugee Act No.130, 1998, Section $3[\mathrm{~b}]$ )

It is important to note that the terms 'refugee' and 'forced migrant' are commonly used interchangeably. This paper uses this conceptual analogy as well. All respondents referred to in this paper belong to this category, even though some of them are still asylum-seekers.

\section{Asylum-seeker}

Whereas refugees include individuals who have been formally granted refugee status under the 1951 UN Convention relating to the Status of Refugees, or under the 1969 OAU Convention Governing the Specific Aspects of Refugee Problems in Africa, asylum-seekers are, according to the United Nations High Commissioner for Refugees (UNHCR), individuals who have applied for asylum and whose claims for refugee status have not yet been determined (UNHCR 2009:5).

\section{Economic migrant}

Unlike refugees who flee their country of origin due to sociopolitical persecution or war and who cannot return home for fear of persecution, economic migrants are those fleeing their country primarily for economic reasons. In terms of both the 1951 UN Convention relating to the Status of Refugees and the 1969 OAU Refugee Convention, economic migrants do not fall under the definition of a 'refugee' and are therefore not eligible for refugee status or international protection. It is, however, important to note that there are unending and often conflicting debates among contemporary scholars and professionals concerning the issue of migration and displacement about the inclusion of economic factors and other natural/environmental and humanmade causes of displacement into the existing, narrow legal definition of a 'refugee' (Black 2001; Stojanov 2004; Bogardi \& Renaud 2006; Betts \& Kaytaz 2009). None of the respondents in the study declared they belonged to this category.

\section{Ethnic identity}

As in culture, the concept of ethnicity is complex and highly contested in socio-anthropological literature (Eagleton 2000:1; Chamba 2007:8). According to Jandt (2007),

ethnic identity refers to identification with and perceived acceptance into a group with shared heritage and cultural traits such as language, religion, and customs that are passed on to the children

(Jandt 2007:17, 25)

Drawing on Schiller and Fouron's understanding of ethnic identity as a sense of belonging to a particular ethnic and having cultural differences with the dominant population (Schiller \& Fouron, cited in Chamba 2007), Chamba (2007:7-9) views different African migrant communities living in Johannesburg as ethnic minority groups within a dominant host population. Similarly, Zmegac $(2005: 199,210)$ argues that the intrusion of any migrant group, whether or not it shares ethnicity, cultural traits, language, and/or structural features with the local population, sets the stage for cultural differentiation and the formation of a separate migrant identity. In this context, ethnicity refers to the differential and often-negotiable relationship between insiders and outsiders (Bekker 2001:4), 'autochthons' and 'allochthons' (Konings 2003:53), where it emerges either as an 'ascribed' or 'self-ascribed' identity (Lindgren 2002:24) within a particular community.

\section{METHODS}

\section{Data collection}

The collection of data presented in this study consisted of an unstructured, face-to-face, in-depth interview schedule, comprising open-ended questions. The interview-guiding questionnaire was elaborated in English and translated into French. Interviews were conducted in either language, according to the respondent's choice. Most interviews were conducted in French $(65 \%)$. It is, however, noteworthy that, at the discretion of the respondent, some interviews consisted of a mixture of French and English. With the exception of one respondent who had her interview at her residence, all other interviews, upon 
the interviewee's proposition, were conducted at the WOLA. This proved very convenient, sparing the researcher costs in terms of time and money. Moreover, conducting interviews at the church - an open/public place - put the prospective respondents at ease - they felt comfortable seeing their churchmates willingly participating in the interviews. Most interviews $(65 \%)$ were tape-recorded with the consent of the respondent. The taped interviews generally took less time (about 20 minutes) than unrecorded interview sessions (almost 1 hour). They were conducted over a period of about 2 months (from November to December 2004). Participant observation was done in advance through church-service attendances, informal visits with some of the church members and, more particularly, through the researcher's active participation in a one-week convention, organized by the WOLA during the first week of November 2004. This socialising process was especially made possible by the fact that the researcher himself is part of the refugee community at large and speaks the languages of the subjects (mostly French, English and Kiswahili).

\section{Demographic profile}

The data were collected from a total of 20 participants in the study - 11 men and 9 women - members of the WOLA. The key informants were the founder and senior pastor of the church, and the church elders. Among the respondents, there were 13 ( 8 men and 5 women) refugees from the Democratic Republic of the Congo (DRC), 2 (1 man and 1 woman) refugees from Angola and 1 female refugee from the Ivory Coast. Also, four South African citizens (two men and two women), full members of the WOLA, were interviewed. About $65 \%$ of the respondents held a position in the church, mostly as choir members and church elders. Among the respondents, nine were married and stayed with their partners and two were single parents. The age group for all respondents was 27-46 years. Most of the respondents resided in Yeoville $(80 \%), 20 \%$ of which stayed within the WOLA premises, the rest staying in Hillbrow (5\%), Bertrams $(5 \%)$, and elsewhere $(10 \%)$. Most of the respondents (about $70 \%$ ) arrived in South Africa and joined the WOLA between 1997 and 2002. It is important to note that all the respondents had previously belonged to a church, mainly Pentecostals (75\%), before leaving their home countries. This trend, to a large extent, confirms Sol's finding that states that 'when the people move, the church moves' (Sol 1982:38). The majority of those who did not belong to a Pentecostal denomination in their home country and who were members of the WOLA at the time of the study belonged to a Roman Catholic Church. When asked why they had changed their denomination, apart from one respondent who indicated to have changed her home denomination (Roman Catholic) to Pentecostal (such as the WOLA) for marriage reasons, the other respondents evoked spiritual reasons to justify their denominational shift. They argued that their denominations could no longer appropriately satisfy their new needs in exile. A research conducted among refugee women in urban Mozambique by Agadjanian (1998:293) yielded a similar result. The study revealed that some Catholic and mainlineProtestant members, as well as refugees who did not declare any religious affiliation, admitted that they sometimes attended a 'zione', or another 'healing' church meeting, to participate in the healing sessions. Note that Pentecostal, or 'charismatic' churches (Synan 1997:293), are commonly referred to as 'healing' churches (Garner 2000:320; Anderson \& Pillay 1997:227). The main reason behind this label is the emphasis these churches place on both spiritual and physical healing. With regard to South African respondents, half were unemployed migrants who were offered accommodation within the premises of the church.

\section{THEORETICAL FRAMEWORK}

\section{Dynamics of integration}

\section{Definitional dilemma}

According to Meyer (2008:6), there are three key 'durable solutions' to the protracted situation of refugees: repatriation to the country of origin, resettlement in a third country, or local integration in the country to which the refugee has fled. Of these, the concept of integration has been a source of increased debate among scholars and others concerned with migration studies.

The definitional complexity of the notion of integration has resulted, epistemologically, in the use of a varied and oftenconflicting terminology, such as local settlement, assimilation, adaptation, local integration versus intermediate integration and so on - thus rendering the concept itself more confusing (Meyer 2008:5). Many of the debates polarise around the meaning of integration, what it entails (requirements and entitlements) and its effects both on migrants and on the host society. Drawing on the contemporary literature on integration, this section briefly discusses the meaning of the concept of integration and the different forms of integration.

\section{Defining integration}

According to Preston (1999:25) 'integration refers to the ability of individuals and groups to interact cohesively, overcoming differences without a breakdown of social relationships and conflict.' Barbara Harrel-Bond's (cited in Dryden-Peterson \& Hovil 2003:3) understanding of integration somehow cross-cuts Preston's definition, where a social cohesion and peaceful coexistence are key elements of integration. She defines integration as 'a situation in which host and refugee communities are able to co-exist, sharing the same resources - both economic and social - with no greater mutual conflict than that which exists within the host community' (Harrel-Bond, cited in Dryden-Peterson \& Hovil 2003:3).

Drawing on Kuhlman, Dryden-Peterson and Hovil (2003) give a more detailed definition of integration, which simply combines a number of characteristics of a successful integration, which include the:

socio-cultural change [that] refugees undergo [and which] permits them to maintain an identity of their own and to adjust psychologically to their new situation, [whether] the friction between host populations and refugees is ... worse than within the host populations itself, [and whether] refugees ... encounter more discrimination than exists between groups previously settled within the host society.

(Kuhlman, Dryden-Peterson \& Hovil 2003:3)

In contrast, Banki (2004:2) deliberately avoids using the term (local) 'integration' as such and prefers to use integration in the 'intermediate' term instead, which she defines as 'the ability of the refugee to participate with relative freedom in the economic and communal life of the host region'. Banki's terminological choice is not incidental. On the one hand, while local integration might also include cultural and political participation, Banki argues, integration in the intermediate term does not emphasise the latter two (2004:2). On the other hand, Banki's use of integration in the intermediate term is based on her understanding of integration not as a permanent solution, but as an intermediate/temporary mechanism intrinsically linked to the liminality of refugeehood. Merkx (cited by Dryden-Peterson \& Hovil 2003:21) implicitly supports Banki's argument when commenting on the UNHCR's refugee self-reliance strategy. He points out that the UNHCR still maintains the terminology of 'local settlement' as one of the 'durable solutions' and prefers not to talk about integration, because this might have connotations of assimilation and permanence. Although the above definitional considerations implicitly attempt to distinguish between permanent and temporary integration, these two forms of integration, to some extent, remain unclear and therefore need further theoretical extrapolation.

\section{Permanent versus temporary integration}

The definitional complexity of the concept of integration has generated a growing debate among migration scholars around the question whether integration implies permanent or temporary 
settlement into the host society. Despite recent thinking - which emphasises both the importance of maintaining individual identity and the possibility of promoting self-reliance pending voluntary return (temporary local integration) (Dryden-Peterson \& Hovil 2003:3), several scholars conceptualise integration as a permanent phenomenon. In this context, for instance, Kibreab (cited in Al-Sharmani 2004:2) describes integration as the 'economic, social and cultural process by which refugees become of the host society on a permanent basis.'

A number of contemporary migration theorists argue that, unlike earlier migrants, contemporary immigrants 'forge and sustain simultaneous multi-stranded social relations that link together their societies of origin and settlement' (Baia 2001:147; Menjivar 2003:26; Levitt 2004:5) and help them to resist assimilation into the 'melting pot' (Peterson 2001:17; Shorter 1991:25; Foner 1987:12). Other migration practitioners and scholars, such as Fedde Groot ${ }^{1}$ and Tebogo Segale ${ }^{2}$ believe that in South Africa local integration has been an option for many refugees (Groo 2004:41), or that integration is inherently essential for their social and economic survival (Segale 2004:50-51).

\section{'Self- integration' within migrant communities (Eyber 2004)}

In his study among forced migrant children and youth in Johannesburg, Eyber expands the concept of integration to include reciprocal relationships and interactions between migrant communities. He argues that '[i]ntegration not only refers to integration with South Africans, but also to integration with any other members of forced migrants' national communities, groups with whom they may share common values, language and lifestyle' (Eyber 2004:74).

In other words, according to Eyber, social networks among various migrant communities and increased interactions between migrants and host citizens (Landau 2006:138) are not only mechanisms of adaptation and acclimatisation to the host community (Malkki 1990), but also important components and stimuli for a local integration.

It is, however, important to say here that in some cases, Eyber's horizontal cohesion may become hard to achieve, especially among migrants or refugees with very sensitive ethnic, cultural or political backgrounds. In most cases, people from the same country may for some reasons carefully avoid close association with other 'exiles', or cling to multiple points of loyalty that allow them to shift within multiple networks (Landau \& Haupt 2007:14-15). For instance, it is hardly reasonable to expect mutual communion between English-speaking and Frenchspeaking Cameroonians (Konings 2003; Nyamnjoh 2005) or between a northern Nigerian Muslim and a southern Nigerian Christian migrant before they can be able to integrate into their countries of asylum. In Mozambique, for instance, Anuruni Tabumara, a Pentecostal Christian pastor in Nambura refugee camp, reported that the Christian 'love of the neighbour' was not strong enough to bridge the gap between Hutus and Tutsis, who refused to pray together and are split into two groups (Sunjic 2004; Waters 1995). Moreover, Landau and Haupt (2007) caution that, even among Somali traders - a more insular community - fragmentation, mistrust and other divisions often trump solidarity ties (Al-Sharmani 2004:25). In fact, premigration ethnic

1.Fedde Groot is the then-Deputy Regional Representative of the United Nations High Commissioner for refugees in South Africa. The quotation is taken from an updated transcript of a verbal presentation Groot delivered at a workshop organised by the Forced Migration Studies Programme at the University of Witwatersrand, 12 Augus 2003. For more details about the whole transcript, see Groot, F., 2004, 'Challenges of the UNHCR's programme for urban refugees in South Africa', in L.B. Landau, (ed.), Forced migrants in the new Johannesburg: Towards a local government response, pp. 37-45, Johannesburg, Forced Migration Studies Programme.

2.Tebogo Segale is the then Regional Director of Black Sash, Gauteng. For more coror (the Johannesburg: Towards a local government response, pp. 37-45. Johannesburg, Forced Migration Studies Programme. or religious antagonisms are likely to replicate among migrants in host communities, albeit perhaps with less intensity than in the country of origin. Indeed, as Conner (1989) explains:

Simply because persons have fled from the same country and, perhaps, from the same source of conflict, does not mean that they have much else in common or, indeed, that they are even compatible ...; varying background characteristics and refugeerelated experiences cause some refugees to be antagonistic toward others.

(Connor 1989:906)

These conflicting behaviours are, however, more likely to take place within 'refugee' communities than within voluntary migrant communities. That is, economic migrants can associate and cohere more easily than political migrants or refugees who, unlike voluntary migrants, bring with them the unavoidable antagonisms attendant to refugee status (Connor 1989:906). In an informal personal interview, one student of the University of the Witwatersrand from the English-speaking part of Cameroon confided that within their (Cameroonian) association in Johannesburg they also have some members from the French-speaking part of Cameroon, 'but unfortunately,' she added, 'as regard to the leadership there are some posts within the association that are only restricted to English-speaking members.' Foner (1987:20) admits that sometimes relationships between immigrant groups are amicable and cooperative, but sometimes they are tinged with conflict and tension linked to cultural and linguistic differences (Al-Sharmani 2004:26).

\section{WORD OF LIFE ASSEMBLY}

\section{Background}

The WOLA was established in December 2000 by Reverend Alves M. Kipa, a pastor from the DRC. The WOLA is an independent Pentecostal church. Though working closely with Rhema Bible Church in Johannesburg and notwithstanding its affiliation with the International Federation of Christian Churches (IFCC) - a large independent church association - the WOLA remains financially and structurally autonomous vis-àvis these two entities. This administrative autonomy seems to be the trend of most of the Pentecostal churches. Rev. Kipa is the sole founder and senior pastor of the church. He received the calling to establish a church many years ago when he was a missionary to Angola. The calling became real when Kipa left another Pentecostal church, which belonged to a Congolese bishop, Daniel Moteba, in Johannesburg Park in 2000. According to Kipa the church was started in his own flat (which he was renting in Hillbrow) and then moved to the Protea Hotel in Berea. After some time, the church moved to a hall on Hillbrow Street in Berea. The hall was also opened to other churches that would use it by paying an affordable rent. When the church had grown to a membership of about 100 in 2001, it moved to Yeoville.

The church has about 450 full members from various nationalities in approximately the following proportions: $95 \%$ Congolese, $2 \%$ South African, $1 \%$ Angolan, and 2\% from other countries (mainly Christians from Nigeria, Zimbabwe, Zambia, Cameroon, Ivory Coast, DRC and Rwanda). As these figures show, the WOLA is essentially composed of foreigners (about 98\%), predominantly refugees from the DRC (about 95\%).

\section{Yeoville}

As have already been stated, the WOLA was established and operates in and from Yeoville. The choice of this site by the WOLA was not incidental. Yeoville is reputed to be one of the most dense urban immigrant areas in Johannesburg. The WOLA is situated on Raleigh, the busy main street, which is filled with people speaking a number of African languages, mostly from the DRC. With its music and high-volume loudspeakers, it has become a popular church in the area. Retailers trading in close 
proximity are able to attend short prayer meetings held between 12:00 and 12:30. The church is also open 7 days a week.

\section{Culture-induced worship}

The first time the researcher attended the church service (23rd May 2004), he heard from afar the sound of loud Congolese music. About 300 people from different socioeconomic backgrounds attend the 3-hour service held every Sunday. Songs are sung in the Lingala language to the high-speed rhythm of accompanying guitars and drums. Interpreters (generally three) who translate from French into English and vice-versa, rotate throughout the service.

\section{Word of Life Assembly - building and maintaining group identity}

In terms of this paper, group identity refers to 'the identification with and perceived acceptance into a group that has a shared system of symbols and meanings as well as norms for conduct' (Jandt 2007:7). In his effort to establish a link between forced migration and religion, Sol (1982:38) points out that 'when the people move, the church moves.' He observes that, when refugees move from one ecclesiastical jurisdiction to another, then pastoral service to refugees in this situation amounts essentially to an effort of co-ordination. Warner (2000) holds a similar view in saying that the role of religion - both as an identity that immigrants bring from the home country and a mode of social participation in the host country - cannot be neglected.

The power of religion in shaping an individual's identity is further put forward by Gunn (2002:16), who asserts that 'as identity, religion is less a matter of theological beliefs than it is an issue of family, culture, ethnicity, and nationality. In the same vein, Gunn insists that ethnicity and religion are closely associated. This study, however, revealed that as far as the Congolese community is concerned, religion is more intimately associated with culture and nationality than ethnicity. During the investigation, it was shown that the WOLA has, to some extent, become a place where both religious and socio-cultural identities are built or maintained among members, specifically Congolese nationals. These group identities are particularly negotiated through daily worship in mother tongues (Lingala and/or French) and Congolese cultural activities and parties organised at the WOLA. When asked about the social activities run by the Church, the pastor stated that every Saturday there is a team of church members that go on a social visit to other church members. He also mentioned that during December of each year the church organises social events in which all church members meet to share food and drinks in order to get to know one another. Socio-cultural identities are also constructed and maintained through the active participation of the church in wedding celebrations and funerals. These important rituals are typically performed according to the Congolese culture. The researcher had the opportunity of witnessing two marriages that took place during interview period.

Furthermore, for a number of respondents, the WOLA has become a family in a foreign city, an oasis in the cosmopolitan desert. Similarly, in his study among Burundian and Rwandese refugees in Tanzania, Sommers (citing Cox 2001:362), concludes that churches give people a place in a community of friends which often stands as a 'surrogate' for an extended family fractured by mobility and change. Asked to give the reasons for not attending other churches in the vicinity, many respondents made statements, such as 'I am comfortable with 'my' church', 'this is 'my' church', or 'I do not need another church'.

Moreover, asked whether they would allow their children to attend a Sunday school at other local churches, all parentrespondents to this question declared that they would not. Differing reasons were given to justify this point. Some parents argued that they are dubious about what their children would learn in other churches. Others would like to have their children around them in the same church for close supervision and control. Other respondents in this category claimed that the church is another home where children must grow spiritually and learn the mentality and culture of their home country, the DRC. In this regard, Thomas (2001:2) asserts that 'religion remains a property of groups, and is especially talked about as the core of culture'.

From these respondents it appears that the church remains the sole place - besides public schools and 'all-nations flats' (referring to the diversity of immigrant population in the area) - where children are not in contact with other foreign children who may put their Congolese culture and identity at risk particularly within the refugee church where religious and sociocultural identities among refugees are negotiated and the risk of acculturation can be minimised. In a bid to adequately achieve this, the refugee church, in addition to its spiritual mission, seeks to play a cultural and traditional role as well.

\section{Social networks among refugees and beyond}

Another important role the WOLA plays on behalf of its members, is helping to establish informal networks between local refugees and between refugees and their home country. This is accomplished mainly by inviting pastors from DRC to preach at the WOLA. For instance, during the WOLA Convention that was held from 02 to 07 November 2004 - which the researcher regularly attended - special visitors, including preachers and singers, came from the DRC. This was an opportunity for some refugee members to interact with the visitors who brought them news, Congolese food and clothing. Most respondents heard about the WOLA through relatives and friends who were already members. Most migrants leave their home country only after connections have been solidly established with relatives and friends in Johannesburg.

Besides relatives and friends establishing connections, the Congolese-owned freight agency, 'Agence Grace Business', which operates within the premises of the WOLA, also facilitates contacts between Congolese immigrants and their home country, particularly in terms of informal import and export transactions. Thus, it is not surprising to find at Yeoville market - where many Congolese retail - several Congolese products, mostly food, such as nyanya (aubergines), fufu (cassava flour), pondu (cassava leaves), mbisi ya ko kauka (dried fish), and clothing items. Respondents who declared to receive financial support from their families in the DRC are more likely to make use of this transnational channel, to which access is relatively easy because of its strategic location.

Social networking among church members extends especially to employment. Most respondents stated they would consult their pastor and other members when in need of employment. It is often in this way refugees have managed to find jobs or contacts to obtain a foothold in the business market in Johannesburg.

\section{BARRIERS TO INTEGRATING INTO LOCAL CHURCHES}

Another important question this paper explores is the integration of refugees into host churches. In terms of forced migration, it is important to investigate the concept of integration in its dual aspects. That is, integration with local people and integration with other members of forced migrants' national communities or groups with whom they share common values, language and lifestyles (Eyber, cited in Landau 2004:74).

Asked whether the respondents had been to any local church in Johannesburg before joining the WOLA, $60 \%$ had been to at least one local church before joining the WOLA. Almost all the respondents who did not attend any other local church (40\%), are those who, prior to leaving their home country, had some 
contacts with family members or friends attending the WOLA. They were immediately ushered and welcomed into the church without necessarily transiting through any other local church. Some did not even feel the need to seek integration into other South African churches.

Two of the main reasons why the respondents left local churches are language and spiritual problems, which means that they could not linguistically and spiritually integrate into local churches as they could at the WOLA.

\section{Language barriers to integrating in local churches}

In order to establish whether language has had an impact on the integration of forced migrants into local churches, respondents were asked to mention the languages they were able to speak and understand. All respondents spoke French fluently. Even the three respondents (Angolan citizens) whose mother tongue was Portuguese declared and demonstrated that they were conversant in French. It can be concluded that language seems to be a major barrier to integration of the predominantly Frenchspeaking refugee community into English-speaking South African churches.

Half of the respondents who arrived in South Africa between 1997 and 2002 could understand and speak English. They have been in the country for a few years and had acquired the language through sermons and business interactions. The respondents who were not conversant in English (47\%) were either Portuguese speakers (28\%) who first had to learn French or Lingala (the main languages in the Congo), or French speakers $(72 \%)$ who have arrived recently.

In sum, both those who could now speak English and those who could not, have had language problems in their integration into domestic churches where English and/or local languages are traditionally used, at least in the earlier stages of their settling in Johannesburg.

The problem of language also prevented Ethiopian refugees from joining the WOLA, prompting them to start their own church (Global Faith Mission Ministries) in 2003, also in one of the halls of the WOLA. In an informal interview with one of the pastoral team members, the researcher was told that Global Faith Mission Ministries flows from the same denominational stream as the WOLA; both churches virtually confess the same faith. Subsequently, when asked why the two churches could not merge to subvert financial costs, the respondent replied that most of the members spoke neither English nor French. The Ethiopian church services are exclusively held in Amharic, the native language of the majority of the members in that church.

Language as a major obstacle to integration was equally raised in earlier research carried out by Macchiavello (2003:20) among refugees in Kampala (Uganda). The study shows that, whilst English-speaking (refugee) preachers had a better chance of finding assistance and work from local churches, the Frenchspeaking preachers, in contrast, enjoyed the advantage of finding work in their own community of refugees where no English is required.

Similarly, in a study done among the Sudanese Nuer Christian refugees in America it was found that in churches where there are pastors from other countries, the English-speaking pastor was always the senior pastor; the other-language pastor was subservient, and therefore also paid less (Sheila, cited in Shandy 2002:217). Their credentials and achievements were relatively devalued by their American counterparts. In addition, the same study revealed that during their process of integrating into existing American Christian churches, some church members regarded the Sudanese newcomers as unwanted and burdensome intruders, causing dissent within the church (Shandy 2002:217-218). The result has been that most of the frustrated pastors alternatively resorted to establishing their own churches among the Sudanese refugee community in the same way the French-speaking pastors in Kampala did (see above).

In contrast to the findings of the abovementioned study and contrary to what the South African public may assume, xenophobia or marginalisation was not reported to be among the barriers to integration of refugees into domestic churches.

\section{Spiritual barriers to integrating into local churches}

For the purposes of this study, a spiritual barrier arises when a worshipper cannot integrate into a church and ultimately leaves because the message preached does not, to some extent, meet his spiritual expectations. Sermons preached in local South African churches seem, to some degree, not to meet the spiritual needs and expectations of the refugees. When the pastor was asked what made Congolese people join the WOLA in a large numbers, he points out that it was mainly because of the nature of the sermons and the fact that French was spoken.

Exploring the causes leading to the spiritual dimension of the problem of integration into local churches is vital. Asked whether the overall spiritual state of his church members influences him in preparing his sermons, the senior pastor of the WOLA plainly declared that, 'though most of the time we receive messages from God and from the readings, we are also sensitive to what is happening in the communities.' 'We cannot preach messages that do not directly concern the flock,' he added. In other words, in knowing intimately the state and status of his congregation, the pastor will selectively prepare sermons conducive to the overall socio-spiritual state of the congregants. Thus, asked about the kind of sermons or themes he thought were the most helpful to the members, the pastor stated that he aimed 'to teach people to have faith in Jesus and trust that God will provide for their needs'. For instance, during the Convention organised by the Church, from 02 to 07 November 2004, most sermons were encouraging members to 'speak blessings' upon themselves, because the theme of the Convention was 'creating with God'. The central message was that God is ready to bless their positive faith. Thus, interpreting the discourse of Jesus to his disciples when sending them out ('The harvest is great, but the laborers are few; therefore pray the Lord of harvest to send out laborers into His harvest' [Luke 10:2, New King James Version]), the pastor told the congregation that '...the year 2005 is a year of plenty blessings. If you have not opened a bank account, it is time to open it now, if you do not have a driver's license, it is time to get it now, if you have not applied for a job, start preparing your C.V., because next year God is going to bless your businesses, bless you with cars and jobs'.

To sum up, linguistic and spiritual factors are likely to make refugees in search of social integration feel socially and spiritually marginalised in local churches. Consequently, some leave these for one that will, to a large extent, accommodate their particular needs and expectations. Most of the respondents who said they had attended services in a local church before joining the WOLA also said they had been to more than one local church, suggesting that each had failed them in some way.

\section{SELF-INTEGRATION WITHIN THE WORD OF LIFE ASSEMBLY}

The fact that most refugees have not been able to integrate into host churches is mainly because of linguistic and spiritual barriers. The researcher wanted to investigate whether integration was consequently achieved within a refugee church (the WOLA). It is important to remember that the church is predominantly composed of refugees from the DRC. Thus, the researcher examined how different groups of refugees interact and integrate within the WOLA. 


\section{Four levels of self-integration within the Word of Life Assembly}

The close association of religion with the culture and nationality is very evident within the WOLA. Members who do not share the culture of the predominantly Congolese members have, to a certain degree, a problem integrating. There appears to be levels of integration, as far as the socio-cultural background of church members is concerned. Even if refugees are generally well integrated in the WOLA, they are, however, not all integrated alike.

\section{Refugee integrating in a refugee community}

The first level of integration is integrating into a refugee community as a whole. This is generally achieved when a refugee finds a church where other people sharing a common refugee status congregate. This type of self-integration is fully achieved within the WOLA, because it is essentially a refugee church.

\section{Religious/spiritual integration}

The second level of integration occurs when a refugee feels spiritually assimilated into the WOLA community. This means the messages or sermons preached in the church, to a large extent, meet the expectations of the members and contribute to their spiritual growth. They are pleased to hear messages that directly or indirectly address their multifaceted and particular needs. Almost all the respondents were of the opinion that the WOLA satisfied these to a large degree in the way it professed the Word of God. This level of self-integration seems to have been successfully achieved.

\section{Cultural integration}

Cultural integration means integrating into a group or community with a similar cultural background. This study found that this level was not fully achieved within the WOLA, especially with regard to church members from other nationalities. This suggests that non-DRC church members maintain their membership within the WOLA because there is tolerance in respect of the third level (cultural integration), inasmuch as the first two levels - integration into refugee community and spiritual congregation - are at least fulfilled. This is particularly the case of South African members attending the WOLA (see below). The inability to culturally integrate into a refugee church is likely to cause refugees who are strongly culture-oriented to look for another refugee church to culturally accommodate them. The cultural dimension of membership within the WOLA seems to override the spiritual one, because even Congolese seasonal businessmen, not members of the WOLA, occasionally attend services while on business in Johannesburg. This leads to the conclusion that, in general, Congolese refugees who joined the WOLA did so not simply because the WOLA is a particular type of church, but because WOLA is, in fact, a 'Congolese community' church. This is why most of foreign churches in Yeoville are often named after nationalities of their leaders or members, such as 'Cameroonian church', 'Ethiopian church' or 'Nigerian church', etc.

\section{Integration of the refugee church itself}

As refugees seek to integrate into the WOLA, likewise the WOLA strives to integrate into the host community. Therefore, not only do church members seek to integrate into the host community and/or churches, but the refugee church itself (a 'foreign entity'), seeks integration into, and approval from, the South African community in general and host faith-based institutions in particular.

During an informal interview on 21 May 2004, Rev. Kipa indicated that the church comprises people of all races - Blacks, Whites, and Indians; however, the researcher did not observe the presence of any Whites or Indians when he attended services. He realised afterwards, that by labelling the WOLA a 'multiracial' church, the pastor meant it was well-integrated into South African society.

Briefly, even though the church counts about $98 \%$ of foreign migrants, it does not wish to be referred to as 'refugee' church or 'foreign' church. This seems to be one of the reasons why, during the interview, the pastor significantly underestimated Congolese membership by reducing it to only $40 \%$, increasing, rather, South African attendance rate to $20 \%$. The researcher's unobstrusive observation and attendance at church services (from June to December 2004) revealed different figures (about 95\% Congolese and about 2\% South Africans). In addition, the researcher also understood the reason why the WOLA's public tracts, including the big informative signboard pitched at the corner of Hunter and Kenmere Street, and its monthly activity program - regularly distributed during Sunday service - are exclusively written in English language, even if about $98 \%$ of the members speak French. This is representative of the WOLA's efforts to integrate into the host community, while simultaneously facilitating and maintaining the integration of its members.

\section{INTEGRATION OF SOUTH AFRICAN MEMBERS INTO THE WORD OF LIFE ASSEMBLY}

As almost all refugee respondents have experienced the problem of integrating into host churches, South African members at the WOLA also encounter the problem of integration, although not in the same degree and manner. Asked how they felt about attending church services with many foreigners, South African respondents said they did not have any problems in principle. However, their comments, to some extent, revealed problems of integration into WOLA. For instance, one South African male respondent mentioned a cultural problem when he interpreted his statement: 'Congolese sisters do not like to be touched on by a brother in Christ', as a sign that the sisters in the WOLA, he explained, 'do not like and trust me.'

\section{Dressing does matter}

The integration of South African members within the WOLA is also affected by differing dressing styles among congregants. A South African woman declared that ' ... the only problem we have lies with the foreign women who do not feel comfortable when we are around; they tell us to not wear short skirts, and command us to cover whatever ... Maybe, they think that we are going to take their husbands'.

This statement reveals, to some extent, an example of an underlying problem of the integration of South African women, who do not see any problem wearing shorts in a church, whereas Congolese women are culturally used to wearing conservative clothes, especially to church. As De Voe (2002) notes in her study of young Somalian women refugees in the United States,

clothing, as a cultural phenomenon, acts as a significant identifier on an individual ... [and] both communicates one's membership in a certain ethnicity and, at the same time, denies, membership in other ethnic groups.

(De Voe 2002:238)

Thus, if clothing signifies a great deal in multiracial and multicultural South African society, it is of great significance in Congolese society, where clothing tends to be one of the main cultural identifiers. During church services, for instance, a quick glance at the congregation would be sufficient for an informed observer to distinguish Congolese women from the rest of the group by their distinctive long clothing, commonly called vikwembe in Swahili, or maputa in Lingala. More than $90 \%$ of the women in the WOLA are Congolese.

In addition, asked about anything South African respondents do not like in the church, or something they would like the church 
to improve, one respondent complained about the loud music in the church. This is another cultural barrier for South African members to fully integrate into Congolese worship traditionally characterised by loud prayer, praise and worship.

One respondent indicated that he felt isolated in the WOLA. Though he affirmed that the pastor was very friendly to him, the respondent nevertheless sadly remarked ' ... the rest of the church members do not care about me; others do not even greet me. Those who greet me are the ones who truly know God.'

To further stress the issue of lack of support to South African members in general, the same respondent gave an instance of a visiting musician from the DRC who performed during the WOLA Convention. According to him, the Congolese musician received far more applause and support from the congregation than the South African musician - 'and he (the South African) is our church member!' he added.

Moreover, when asked about what they would like the church to improve, some respondents suggested that the church should show transparency in providing assistance to its members. In this regard, one respondent indicated that his fellow church members from the DRC, 'who are unemployed like me, seem to have no problem getting food and clothing'. In other words, the respondent suspects that some Congolese church members may get assistance from the church, only because they are Congolese. The researcher considers such a judgement as a further indicator of a lack of integration or, to say the least, a limited integration of South African members into a refugee established church.

The last, but not the least, evidence of the problem of integration of South African members into the WOLA, was drawn from the statement of one respondent (woman) before interviews were conducted. When she was contacted to arrange for an interview, she was very excited to take part and hastily told the researcher 'I will also tell my neighbour' - who is another South African lady and a WOLA member, adding that '[s] he also has got some complaints about the church'. It is significant that this statement was made before any interviews were conducted and that the researcher had not yet told interviewees his research aimed at identifying problems they might be facing within the church.

This leads to the question: if South African members encounter problems of integration within the WOLA, why do they keep on attending? The advantages South African members have within the WOLA far outweigh the problems they have. All the South African members who were interviewed were members of the church choir. This was very important to them. In fact, when some South African respondents, who had been to other local churches before joining the WOLA, were asked to give reasons why they left, some said they left because they were not given opportunity to exercise their talents. South Africans are given pulpit to proudly and confidently sing their 'Zulu' worshipping songs, with which the French-speaking congregation is quite familiar. Another reason why South Africans attend the WOLA is because when they are unemployed they are given accommodation within the premises of the church, free of charge.

\section{CONCLUSION}

The study indicates clearly that the WOLA has been able to integrate refugees who could not otherwise integrate in local or domestic churches in Johannesburg. Four levels of integration were identified within the Church: a refugee integrating into a refugee community, cultural and spiritual integration, the integration of the Church into the South African community in general and host faith-based institutions in particular. Nevertheless, this integration is not complete for all members. Indeed, integration is achieved among members who, in general, share the same common refugee status and similar experiences.
The degree of integration remains largely dependent on the members' socio-cultural backgrounds. The study revealed that refugees from the DRC - the majority - are more integrated than other nationalities in the church, especially compared to South African members attending the same church. With regard to the latter group, the study revealed that their integration into the WOLA remains limited, mainly because of socio-cultural differences (clothing, music, language, etc.). Their continued attendance seems to be dependent on a number of advantages that the WOLA affords them. Cultural and linguistic problems were identified as major barriers for refugees to integrate into local churches, thereby becoming important contributing factors to the establishment of immigrant churches within host communities.

\section{REFERENCES}

Al-Sharmani, M., 2004, Refugee livelihoods: Livelihood and diasporic identity constructions of Somali refugees in Cairo, New issues in refugee research: Working paper 104, UNHCR, Geneva.

Anderson, H. \& Pillay, G., 1997, 'The segregated spirit: The Pentecostals', in R. Elphick \& R. Davenport (eds.), Christianity in South Africa: A political, social, and cultural history, pp. 227241, David Philip Publishers, Claremont.

Baia, L., 2001, 'Rethinking transnationalism: National identities among Peruvian Catholics in New Jersey', in A. Peterson M. Vasquez \& P. Williams (eds.), Christianity, social change, and globalization in the Americas, pp. 147-164, Rutgers University Press, New Brunswick.

Banki, S., 2004, Refugee integration in the intermediate term: A study of Nepal, Pakistan, and Kenya, New Issues in Refugee Research: Working Paper 108, UNHCR, Geneva.

Bekker, S., 2001, 'Identity and ethnicity', in S. Bekker et al. (eds.), Shifting African identities, Vol II in the series: Identity? Theory, Politics, History, pp. 1-20, Human Sciences Research Council, Pretoria.

Betts, A. \& E. Kaytaz, 2009, National and international responses to the Zimbabwean exodus: Implication for the refugee protection regime, New Issues in Refugee Research: Working Paper 175, UNHCR, Geneva.

Black, R., 2001, 'Fifty years of refugee studies: From theory to policy', International Migration Review 35(1), 57-78.

Burwell, R., Hill, P. \& Wicklin, J., 1986, 'Religion and refugee resettlement in the United States: A research note', Review of Religious Research 27(4), 356-366.

Chamba, L., 2007, Forced migrants and access to services in Johannesburg, commissioned by the Coordinating Body of Refugee Communities and the 'Netherlands Institute for Southern Africa'.

Connor, K., 1989, 'Factors in the residential choices of selfsettled Afghan refugees in Peshawar, Pakistan', International Migration Review 23(4), 904-932.

De Voe, P., 2002, 'Symbolic action: Religion's role in the changing environment of young Somali women', Journal of Refugee Studies 15(2), 234-246.

Dryden-Peterson, S. \& Hovil, L., 2003, 'Local integration as a durable solution: Refugees, host population and education in Uganda', New Issues in Refugee Research, Working Paper 93, UNHCR, Geneva.

Eagleton, T., 2000, 'The idea of culture', Blackwell Publishers, Wiley-Blackwell.

Eyber, C., 2004, 'Forced migrant children and youth in Johannesburg', in L. Landau (ed.), Forced migrants in the new Johannesburg: Towards a local government response, pp. 70-76, Forced Migration Studies Programme, University of the Witwatersrand, Johannesburg.

Fenggang, Y. \& Ebaugh, H., 2001, 'Transformations in new immigrant religions and their global implications', American Sociological Review 66(2), 269-288.

Foner, N. (ed.), 1987, New immigrants in New York, Columbia University Press, New York. 
Garner, C., 2002, 'Religion as a Source of Social Change in the New South Africa', Journal of Religion in Africa 30, 310-343.

Gozdziak, E. \& Shandy, D., 2002, 'Religion and spirituality in forced migration', Journal of Refugee Studies 15(2), 129-135.

Groot, F., 2004, 'Challenges of the UNHCR's programme for urban refugees in South Africa', in L. Landau (ed.), Forced migrants in the new Johannesburg: Towards a local government response, pp. 37-42, Forced Migration Studies Programme, University of the Witwatersrand, Johannesburg.

Gunn, J., 2002, The complexity of religion in determining refugee status: Roundtable on religion-based refugee claims, viewed 15 January 2005, from http://www.unhcr.ch/cgi-bin/texis/ vtx/home+twwBmec8JLK.

Harrel-Bond, B., 1999, 'The experience of refugees as recipients of aid', in A. Ager (ed.), Refugees: Perspectives on the experience of forced migration, pp. 93-104, Cassell, New York.

Jandt, E., 2007, An introduction to intercultural communication: Identities in a global community, 5th edn., Sage Publications, Thousand Oaks.

Kim, I., 1987, 'The Koreans: Small business in an urban frontier', in N. Foner (ed.), New immigrants in New York, pp. 219-241, Columbia University Press, New York.

Konings, P., 2003, 'Religious revival in the Roman Catholic Church and the autochthony-allochthony conflict in Cameroon', Africa: Journal of the International African Institute 73(1), 31-56.

Landau, L. \& Haupt, I., 2007, 'Tactical cosmopolitanism and idioms of belonging: Insertion and self-exclusion in Johannesburg', paper prepared for Cosmopolitan citizenship: A symposium, School of Architecture and Planning, University of the Witwatersrand, Johannesburg, April 18-19.

Levitt, P., 2004, 'Redefining the boundaries of belonging: The institutional character of transnational religious life', Sociology of Religion 65(1), 1-18.

Lindgren, B., 2002, The politics of Ndebele ethnicity: Origins, nationality, and gender in Southern Zimbabwe, Uppsala University, Sweden.

Macchiavello, M., 2003, 'Forced migrants as an under-utilized asset: Refugee skills, livelihoods, and achievements in Kampala, Uganda', UNHCR New Issues in Refugee Research, Working Paper No.95, viewed 20 January 2005, from http:// www.unhcr.ch/cgi-bin/texis/vtx/home?page=search.

Malkki, L., 1992, 'National geographic: The rooting of peoples and the territorialization of national identity among scholars and refugees', Cultural Anthropology 7(1), 24-44.

Menjivar, C., 2003, 'Religion and immigration in comparative perspective: Catholic and Evangelical Salvadorans in San Francisco, Washington, DC and Phoenix', Sociology of Religion 64(1), 21-45.

Meyer, S., 2008, FMO research guide on local integration. Forced migration online, viewed 11 February 2010, from http://www.forcedmigration.org/guides/fmo045.
Nyamnjoh, F., 2005, 'Africa's media, democracy and the politics of belonging', Zed Books, London.

Nzayabino, V., 2005, 'The role of refugee established churches in the lives of forced migrants: A case study of Word of Life Assembly in Yeoville, Johannesburg', MA thesis, Forced Migration Studies, University of the Witwatersrand.

Organization of African Unity (OAU), Convention Governing the Specific Aspects of Refugee Problems in Africa, AddisAbaba, Ethiopia, 10 September 1969, viewed 06 April 2010, from http://www.africa union.org/official_Documents/ treaties_\%20Conventions_\%20Protocols/Refugee_Convention. pdf.

Peterson, A., Vasquez, M. \& Williams, P. (ed.), 2001, Christianity, social change, and globalization in the Americas, Rutgers University Press, New Brunswick.

Portes, A., 1969, Dilemmas of a Golden Exile: Integration of Cuban refugee families in Milwaukee, American Sociological Review 34(4), 505-518.

Government Gazette 402 (19544), Refugee Act No.130, 1998, Cape Town.

Segale, T., 2004, 'Forced migrants and social exclusion in Johannesburg', in L. Landau (ed.), Forced migrants in the new Johannesburg: Towards a local government response, pp. 46-53. Forced Migration Studies Programme, University of the Witwatersrand, Johannesburg.

Shandy, J., 2002, 'Nuer Christians in America', Journal of Refugee Studies 15(2), 213-221

Sol, J. (ed.), 1982, Refugees: A challenge to South African churches - a ministry to refugees handbook, South African Council of Churches, Pietermaritzburg.

Sommers, M., 2001, 'Young, male and Pentecostal: Urban refugees in Dar es Salaam, Tanzania', Journal of Refugee Studies 14(4), 347-370.

Stojanov, R., 2004, 'Environmental Refugees: Introduction', Geographica 38, 77-83.

United Nations, 1951, 'Convention relating to the Status of Refugees', viewed 16 September 2009, from http://www. unhcr.org/protect/PROTECTION/3b66c2aa10.pdf

United Nations High Commissioner for Refugees (UNHCR), 2009, 2008 Global trends: Refugees, asylum-seekers, returnees, internally displaced and stateless persons, Geneva.

Warner, S., 2000, 'The new immigration religion: An update and appraisal', EPIcenter, the newsletter for the International Center for Migration, Ethnicity and Citizenship 5, viewed 15 May 2004, from http://www.infoplease.com/ce6/world/ A0813218.html.

Waters, T., 1995, 'Tutsi social identity in contemporary Africa', The Journal of Modern African Studies 33(2), 343-347.

Zmegac, C., 2005, 'Ethnically privileged migrants in their new homeland', Journal of Refugee Studies 18(2), 199-215. 